Astronomical Navigation Tables

(Air Publication 1618.) Vol. A : Latitudes $0^{\circ}-4^{\circ}$ North and South. Prepared by H.M. Nautical Almanac Office on behalf of the Air Ministry. Pp. 233. (London : H.M. Stationery Office, n.d.) 7s. $6 d$. net.

TN 1936 the Nautical Almanac Office undertook, by 1 agreement with the Admiralty, the preparations of an "Air Almanac" and of "Astronomical Navigation Tables" for astronomical navigation in the air. The "Air Almanac" has always been on sale to the general public; but the "Tables" have been restrict $\epsilon$ d to official use and are now for the first time being placed on general sale.

The complete set of tables comprises fifteen volumes, catering for all latitudes from $79^{\circ} \mathrm{N}$. to $79^{\circ} \mathrm{S}$. Fourteen of these cover belts of $5^{\circ}$ of latitude both north and south of the equator ; the fifteenth covers the ten degrees $70^{\circ}-79^{\circ}$. The tables are designed to facilitate the calculation of the altitude and azimuth of an observed heavenly body. For each degree of latitude and for each degree of hour-angle, the altitude is given to the nearest minute of arc and the azimuth to the nearest degree for each of twenty. two selected bright stars, well distributed over the sky, within the range of altitudes between $10^{\circ}$ and $80^{\circ}$, and also for each degree of declination from $28^{\circ} \mathrm{S}$. to $28^{\circ} \mathrm{N}$., which covers the range of declination for the sun, moon, and planets. The computed altitudes include the effect of refraction at a height of $5,000 \mathrm{ft}$., but a table of corrections for other heights, from sea-level, for surface navigation, to $40,000 \mathrm{ft}$., is given.

In order to avoid interpolation with three arguments, the tables are intended to be used with an assumed position, corresponding to tabulated values of latitude and of hour-angle. No provision is therefore made for interpolation other than for declination.

The tables are well designed and well printed, and their convenience in practice has been amply proved by their extensive use during and since the War by the Royal Air Force. Though intended primarily for air navigation, they are equally useful for surface navigation, subject to the limitations of accuracy inherent in the tabulations of altitudes to the nearest minute of are.

H. SPENCER JONES

\section{Regions and Nations of the World}

By Assoc. Prof. Earl E. Lackey and Asst. Prof. Esther S. Anderson. Reprint. Pp. xix +489. (New York: D. Van Nostrand Co., Inc.; London : Macmillan and Co., Ltd., 1947.) 26s. net.

THE authors have here tried to choose what they think most useful for a course in world geography to be given in a year, or abbreviated into a semester, in an American college or university. It requires "few if any additional references or assigned reading to be provided by the instructor" ; the reviewer would add here 'more's the pity'. The scheme for each region is $(a)$ natural features, $(b)$ cultural features leading on to urban centres, and sometimes on to a short appraisal of current problems or of prospects. The book has many illustrations and the photographs are often very telling; the maps are of poor quality. Cultural features are usually notes on commercial and political matters; they vary greatly in appositeness but are sometimes quite to the point, though the accounts of cities are so short as often to be trivial. The book has 100 pages given to the United States and 37 to the rest of North America, 60 to South
America, about 140 to the whole of Eurasia, 38 to Africa and 30 to Australasia and Antarctica. The aim is to say something about every region and every country and every really big town, and to follow as uniform a plan as possible, all commendable in a certain measure as facilitating reference to a limited extent; but the book needs vitalizing.

Surely a course of this kind should aim at giving a vision of vital change going on everywhere, a vision that would tempt students who are interested to follow the subject for themselves thereafter. One judges from the text that the writers have not much knowledge of what Edinburgh or Zurich, to take two instances, mean in the human story; but it would be unprofitable to go on with hundreds of instances of missing the point. We must be thankful that geography is being increasingly recognized in the United States and hope that its exponents there may improve on this type of book; so many American books have such high quality already. H. J. F.

\section{The Psychology of Ego-Involvements}

Social Attitudes and Identifications. Psychology.) Pp. viii+525. (New York: John Wiley and Sons, Inc. ; London : Chapman and Hall, Ltd., 1947.) 36s. net.

THE chief aim of this competent work is to show that the 'ego', or rather the 'ego-involved reaction', is an outcome of social forces impinging upon the individual throughout his life. The authors are deeply versed in the literature of experimental psychology, sociology and social anthropology, and by skilfully weaving together relevant results of research in these fields bring abundant evidence in support of their thesis.

Starting with an analysis of the theory of attitudes and making full use of the important concept of 'frame of reference', they trace the growth of the ego through infancy and childhood and its re-formation in adolescence. This is followed by a valuable treatment of the structural properties of diverse groups in which the participant 'egos' take their shape, and a study of ego pathology in conditions of stress, deprivation and group disintegration. Phenomena brought to light are further illustrated by reference to drama and fiction. Finally, there is a critique of the psychoanalytic theory of the ego, a critique which many readers will think too severe in its conclusions.

The book is a substantial contribution to social psychology. Its robust attention to concrete situations of social life gives it realism without loss of scientific value. As the authors rightly say, scientific objectivity is derived from the methods employed and not from the aloofness of the worker. ЈоHN CоHEN

\section{Bird Life in Cornwall}

By B. H. Ryves. Pp. $256+16$ plates. (London and Glasgow: Wm. Collins, Sons and Co., Ltd., 1948.) 10s. $6 d$. net.

T OCAL ornithologies to be of value must be precise, 1 and they therefore tend to become lists; however, Lieut.-Colonel B. H. Ryves in his volume dealing with bird life in the most southerly counties of England has cleverly avoided this by dividing his book into two parts. The first includes an account of Cornwall and its bird haunts and has chapters on such outstanding Cornish birds as the chough, raven, peregrine, common buzzard and Montagu's harrier. In the second part we have a guide to the birds of Cornwall with notes on behaviour, etc. The 